\title{
Kesiapan Guru Dalam Menggunakan Teknologi Informasi Untuk Pembelajaran Kurikulum 2013 Pada SMP Negeri Kota Palembang
}

\author{
Deasy Arianty, Darius Antoni \& Muhamad Akbar \\ Universitas Bina Darma \\ Email: ariantydeasy@gmail.com
}

\begin{abstract}
The 2013 curriculum is a new curriculum issued by the Ministry of Education and Culture of the Republic of Indonesia. The 2013 curriculum itself is a curriculum that prioritizes understanding, skills, and character education, where students are required to understand the material, be active in the discussion and presentation process and have high manners and discipline. This curriculum officially replaces the Education Unit Level Curriculum which has been implemented since 2006. However, there are still many teachers who find it difficult to apply this approach in teaching and using learning media, one of which is information technology. The results of the research explanation can be revealed that the readiness of teachers to use information technology in the 2013 curriculum is around $79 \%$ ready and categorized as high, in this case technology and information are not only used in the computer field but can also be used as learning media in the 2013 curriculum-scientific approach , without eliminating the essence of the basic concepts of the 2013 curriculum.
\end{abstract}

Keywords: Curriculum, IT, Scientific approach, teachers

\section{Pendahuluan}

Perkembangan teknologi informasi saat ini sudah dapat dirasakan dan dimanfaatkan oleh setiap masyarakat. Pendidikan merupakan salah satu faktor penentu keberhasilan pembangunan dalam upaya meningkatkan sumber daya manusia yang berkualitas. Pendidikan juga dapat mengembangkan kemampuan, ilmu pengetahuan dan teknologi.

Pendidikan juga dapat menentukan kemajuan sebuah negara. Negara di dunia berkompetisi memajukan mutu pendidikan untuk mendapat peringkat teratas dalam kualitas pendidikan. Untuk menciptakan pendidikan yang bermutu, maka suatu Negara membutuhkan adanya standar proses pendidikan dan kurikulum yang mampu mewadahi tuntutan kebutuhan pendidikan. Dengan pertimbangan kemajuan teknologi informasi yang pesat serta potensi pemanfaatannya secara luas, membuka peluang bagi guru untuk dapat memanfaatkan teknologi informasi secara optimal dengan memfasilitasi aktivitas pembelajaran yang inovatif.

Permendikbud No. 24 tahun 2016 menyatakan tentang pemberlakuan kurikulum tahun 2013 bahwa seorang guru diwajibkan untuk menguasai teknologi informasi dalam pembelajaran. Peran teknologi informasi menjadi sangat penting dalam proses pembelajaran karena dapat meningkatkan efisiensi dan efektivitas pembelajaran sehingga dapat meningkatkan daya tarik dan perhatian peserta didik.

Dalam Permendiknas Nomor 16 Tahun 2007 mengenai Standar Kualifikasi Akademik dan Kompetensi Guru terdapat empat kompetensi yang harus dikuasai oleh guru, dua diantaranya kompetensi pedagogik dan kompetensi profesional. Kompetensi pedagogik meliputi pemanfaatan teknologi informasi untuk kepentingan pengelolaan pembelajaran, dan kompetensi profesional meliputi memanfaatkan teknologi informasi untuk berkomunikasi dan mengembangkan keprofesian berkelanjutan. Kedua kompetensi tersebut menjadi landasan 
pemanfaatan teknologi informasi dalam pembelajaran merupakan sesuatu yang sangat penting untuk menunjang keberhasilan dalam pencapaian tujuan pembelajaran. Namun, masih banyak guru yang merasa kesulitan menerapkan pendekatan tersebut dalam mengajar dan menggunakan media pembelajaran salah satunya teknologi informasi. Teknologi informasi tidak hanya digunakan dalam hal bidang komputer tetapi juga dapat digunakan sebagai media pembelajaran pada kurikulum 2013-scientific approach-, dengan tidak menghilangkan esensi dari konsep dasar kurikulum 2013.

Dengan kemampuan menggunakan teknologi informasi dan mengintegrasikannya dalam aktivitas pengajaran, guru diharapkan dapat mengantarkan para siswa memenuhi kompetensi tersebut. Ada banyak kegiatan dalam pendidikan dan pengajaran yang bisa dilakukan guru dengan bantuan teknologi informasi, yaitu diantaranya adalah administrasi, komunikasi, pengembangan sumber belajar, pembuatan rencana pembelajaran , penyampaian bahan ajar, evaluasi, aktivitas dalam dan luar kelas, belajar mandiri, hingga pengembangan profesi guru.

\section{Tinjauan Literatur}

Teknologi adalah pengembangan dan aplikasi dari alat, mesin, material dan proses yang menolong manusia menyelesaikan masalahnya. Informasi adalah hasil pemrosesan, manipulasi dan pengorganisasian/penataan dari sekelompok data yang mempunyai nilai pengetahuan (knowledge) bagi penggunanya . Pengertian teknologi informasi menurut beberapa ahli teknologi informasi :

1. Teknologi Informasi adalah studi atau peralatan elektronika, terutama komputer, untuk menyimpan, menganalisa, dan mendistribusikan informasi apa saja, termasuk kata-kata, bilangan, dan gambar (kamus Oxford, 1995)

2. Teknologi Informasi adalah seperangkat alat yang membantu anda bekerja dengan informasi dan melaksanakan tugas-tugas yang berhubungan dengan pemrosesan informasi (Haag \& Keen, 1996)

3. Teknologi Informasi tidak hanya terbatas pada teknologi komputer (software \& hardware) yang digunakan untuk memproses atau menyimpan informasi, melainkan juga mencakup teknologi komunikasi untuk mengirimkan informasi (Martin, 1999)

4. Teknologi Informasi adalah segala bentuk teknologi yang diterapkan untuk memproses dan mengirimkan informasi dalam bentuk elektronis (Lucas, 2000)

5. Teknologi Informasi adalah teknologi yang menggabungkan komputasi (komputer) dengan jalur komunikasi berkecepatan tinggi yang membawa data, suara, dan video (William \& Sawyer, 2003)

Di dalam dunia pendidikan manfaat komputer adalah sangatlah besar terutama dalam hal mencari referensi. Berikut ini manfaat komputer dibidang pendidikan :

1. Pendidik dapat memiliki variasi mengajar dengan menggunakan komputer. Menurut Sudjana dan Rivai (1989) ada beberapa model pembelajaran dengan komputer, yaitu model latihan dan praktek (drill and practice), model tutorial (tutorials), model penemuan (problem solving), model simulasi (simulations), dan model permainan (game). Model pembelajaran ini dapat digunakan pendidik dalam kegiatan pembelajaran agar pembelajaran lebih menarik sehingga dapat membantu peserta didik untuk mengembangkan pengetahuan mereka. 
2. Kemampuan belajar peserta didik dapat meningkat dengan adanya fasilitas komputer. Mereka dapat mengerjakan tugas - tugas dengan kreatif melalui komputer karena komputer mampu menampilkan teks, warna, gerak, suara, video, gambar dan lainnya.

3. Kecerdasan psikomotorik siswa dapat terangsang dengan adanya pendidikan yang berbasis teknologi. Siswa dapat menentukan jenis atau arah pendidikan yang mana yang bermanfaat baginya untuk meningkatkan kualitas pendidikannya.

4. Komputer adalah media atau alat bantu untuk memudahkan pekerjaan. Akan tetapi, kunci terciptanya kualitas pendidikan yang baik adalah dari dalam diri pengguna komputer tersebut baik pendidik maupun peserta didik. Tanpa adanya kemauan dan ketekunan dari peserta didik, untuk belajar, komputer hanya akan menjadi benda mati atau pajangan yang tidak memiliki manfaat.

Kemajuan di bidang teknologi, komputer dan telekomunikasi juga mendukung perkembangan teknologi internet. Internet adalah suatu jaringan besar yang dibentuk oleh interkoneksi jaringan komputer yang menghubungkan orang dan komputer di seluruh dunia melalui saluran telepon, satelit dan sistem komunikasi lainnya (Antoni, Akbar \& Fatoni, 2018; Antoni, Fikari, Akbar \& Jie, 2018; Akbar \& Antoni, 2019; Ariana, Azim \& Antoni, 2020; Antoni, Jie \& Abareshi, 2020).

\subsection{Tingkat Pemahaman teknologi informasi}

Pemahaman pemakai (guru) tentang teknologi informasi akan menentukan keberhasilan suatu sistem informasi, sebaliknya ketidaktahuan atau kecemasan pemakai terhadap sistem yang baru dapat menyebabkan kegagalan dalam menggunakan teknologi informasi. Peningkatan pemahaman pemakai tentang sistem informasi juga berpengaruh terhadap keberhasilan dalam memanfaatkan teknologi informasi (Sunarti dan Nur, 1998 dalam Rizki, 2006).

Dalam berbagai hasil penelitian dan tulisan mensinyalir ada sekitar $70 \mathrm{~s} / \mathrm{d} 90 \%$ guru dalam pemanfaatan kemajuan teknologi informasi dalam proses pembelajaran dan kegiatan lain dianggap masih gagap teknologi. Jika kondisi ini benar demikian, alangkah menyedihkan, sebab di tengah didengungkannya pembelajaran interaktif (e-learning) yang juga harus melibatkan guru-gurunya dalam bidang studi apapun, alangkah ironis kalau gurunya sendiri tidak pernah sedikitpun menjamah teknologi informasi yang kini telah merambah kesemua sisi kehidupan manusia.

\subsection{Dukungan Lembaga Pemerintah}

Kurikulum 2013 merupakan kurikulum baru yang dikeluarkan oleh Kementrian Pendidikan dan Kebudayaan Republik Indonesia. Kurikulum 2013 sendiri merupakan sebuah kurikulum yang mengutamakan pada pemahaman, skill, dan pendidikan berkarakter, dimana siswa dituntut untuk paham atas materi, aktif dalam proses berdiskusi dan presentasi serta memiliki sopan santun dan sikap disiplin yang tinggi. Kurikulum ini secara resmi menggantikan Kurikulum Tingkat Satuan Pendidikan yang sudah diterapkan sejak 2006 lalu. (Tuti, 2014) Ketidaksiapan dan ketidapahaman yang utuh dari para stakehoder di sekolah sekolah, terutama para guru dan peserta didik terhadap kurikulum 2013 membuat pelaksanaannya timpang dan tidak sesuai dengan ekspektasi. Bagi kebanyakan guru dan peserta didik, Kurikulum 2013 pun dianggap memberatkan. Sebagai konsekuensinya, Menteri Pendidikan dan Kebudayaan, Anies Baswedan, mengambil jalan tengah dengan membuat kebijakan pembatasan penerapan kurikulum 2013. 


\section{Metode Penelitian}

Tajul Arifin (2013) menjelaskan desain penelitian dapat didefinisikan sebagai rencana dan struktur penyelidikan yang digunakan untuk memperoleh bukti-bukti empiris dalam menjawab pertanyaan penelitian. Sedangkan Husein Umar (2005) menyebutkan desain penelitian adalah rencana dan struktur penyelidikan yang dibuat sedemikian rupa agar diperoleh jawaban atas pertanyaan-pertanyaan penelitian. Beberapa pendapat ahli yang disimpulkan Juliansyah (2015) bahwa desain penelitian terbagi menjadi dua, yaitu secara menyeluruh dan secara parsial. Secara menyeluruh artinya semua proses yang diperlukan dalam perencanaan dan pelaksanaan penelitian, sedangkan secara parsial merupakan penggambaran dari hubungan antar variable, pengumpulan data dan analisi data.

Melihat dari definisi desain penelitian baik menurut Tajul Arifin, Juliansyah dan Husein Umar diatas, penulis beranggapan bahwa desain penelitian merupakan sebuah proses yang dilakukan terhadap perencanaan dan pelaksanaan penelitian yang dilakukan dengan cara memilih, mengumpulkan dan menganalisis data yang diteliti pada waktu tertentu yang pada akhirnya dibuat sebuah kesimpulan dari hasil penelitian tersebut.

Dalam penelitian ini desain penelitian yang digunakan adalah desain penelitian deskriptif. Juliansyah (2015) menjelaskan tujuan desain penelitian deskriptif adalah untuk mendiskripsikan karakteristik suatu gejala, peristiwa, kejadian yang terjadi saat ini, sedangkan menurut Sumadi (2014) tujuan dari penelitian deskriptif adalah untuk membuat pecandraan secara sistematis, factual dan akurat mengenai fakt-fakta dan sifat populasi atau daerah tertentu.

Adapun variabel dalam penelitian ini adalah variabel tunggal yaitu kesiapan guru dalam menggunakan teknologi informasi untuk pembelajaran kurikulum 2013 pada SMP Negeri Palembang.

Operasional variabel merupakan proses penguraian variabel penelitian ke dalam subvariabel, dimensi, indikator subvariabel, dan pengukuran. Variabel-variabel yang akan diukur dan diuji dalam penelitian ini merupakan variabel-variabel operasional dimana terdapat dua variabel yang menggambarkan hubungan sebab akibat. Variabel yang satu memberi pengaruh atau dipengaruhi variabel lain dan hubungan tersebut terjadi dengan sendirinya. Berdasarkan judul penelitian yang telah dikemukakan diatas yaitu : "Kesiapan guru dalam menggunakan teknologi informasi untuk pembelajaran kurikulum 2013 pada SMP Negeri kota Palembang”, maka variabel-variabel yang diteliti dapat dibedakan menjadi dua yaitu:

\section{Variabel Bebas (Independent Variable)}

Menurut Sugiyono (2008) definisi variabel bebas adalah variabel yang mempengaruhi atau yang menjadi sebab perubahannya atau timbulnya variabel dependent (terikat). Dalam penelitian ini yang merupakan variable bebas adalah Faktor-faktor yang mempengaruhi aplikasi Teknologi Informasi.

Adapun faktor-faktor yang mempengaruhi kesiapan guru dalam teknologi informasi tersebut adalah :

1. Pemahaman guru dalam teknologi informasi

2. Dukungan dari manajemen puncak (Kepala Sekolah)

3. Dukungan dari lembaga pemerintah (kementrian Pendidikan dan Disdikpora). 
4. Sedangkan kesiapan guru dalam teknologi informasi sendiri merupakan variable bebas dari pelaksanaan kurikulum 2013.

\section{Variabel Terikat (Dependent Variable)}

Menurut Sugiyono (2005) definisi variabel terikat adalah variabel yang dipengaruhi atau yang menjadi akibat, karena adanya variabel bebas. Adapun variable terikat pada penelitian ini adalah : Kesiapan guru dalam aplikasi teknologi informasi pada kurikulum 2013.

Selengkapnya mengenai operasionalisasi variabel dapat dilihat pada tabel 2. di bawah ini:

Tabel 2. Definisi Operasional Variabel.

\begin{tabular}{|c|c|c|c|}
\hline Variabel & Definisi & Indikator & Skala \\
\hline \multirow{6}{*}{$\begin{array}{l}\text { Tingkat } \\
\text { pemahaman IT }\end{array}$} & \multirow{6}{*}{$\begin{array}{l}\text { Pemahaman } \\
\text { tentang } \\
\text { apa dan } \\
\text { bagaimana IT } \\
\text { itu. }\end{array}$} & - Pengetahuan tentang computer & \multirow{6}{*}{$\begin{array}{l}\text { Skala } 1-5 \\
\text { dengan pilihan } \\
\text { jawaban : } \\
\text { - } \quad \text { Sangat tinggi } \\
\text { - } \quad \text { Tinggi } \\
\text { - } \quad \text { Sedang } \\
\text { - } \quad \text { Rendah } \\
\text { - } \quad \text { Sangat rendah }\end{array}$} \\
\hline & & $\begin{array}{l}\bullet \quad \text { Pengetahuan tentang manfaat } \\
\text { aplikasi IT }\end{array}$ & \\
\hline & & - Latar belakang pendidikan & \\
\hline & & $\begin{array}{l}\text { - Pemakaian software Ms.word, } \\
\text { exel, power point }\end{array}$ & \\
\hline & & $\begin{array}{l}\bullet \text { Pemakaian computer dan } \\
\text { jaringan }\end{array}$ & \\
\hline & & - Pemakaian internet & \\
\hline
\end{tabular}

\begin{tabular}{|c|c|c|c|}
\hline Variabel & Definisi & Indikator & Skala \\
\hline \multirow{4}{*}{$\begin{array}{c}\text { Dukungan } \\
\text { manajemen } \\
\text { puncak ( kepala } \\
\text { sekolah ) }\end{array}$} & $\begin{array}{l}\text { Aktivitas nyata dari } \\
\text { manajemen puncak }\end{array}$ & $\begin{array}{l}\text { - Dukungan sumberdaya } \\
\text { keuangan }\end{array}$ & \multirow{4}{*}{\begin{tabular}{cc}
\multicolumn{2}{l}{ Skala $1-5$} \\
dengan pilihan \\
jawaban : \\
$\qquad \begin{array}{l}\text { - } \\
\text { tinggi }\end{array}$ \\
$\bullet$ & Tinggi \\
$\bullet$ & Sedang \\
- & Rendah \\
$\bullet$ & Sanga
\end{tabular}} \\
\hline & $\begin{array}{ll}\text { termasuk persepsi } \\
\text { dan sikap tentang }\end{array}$ & $\begin{array}{cc}\bullet & \text { Partisipasi manajemen } \\
\text { puncak } & \end{array}$ & \\
\hline & $\begin{array}{l}\text { pentingnya } \mathrm{IT} \text { di } \\
\text { dalam pelaksanaan } \\
\text { K13 }\end{array}$ & $\begin{array}{l}\text { - Keterlibatan manajemen } \\
\text { puncak }\end{array}$ & \\
\hline & & & \\
\hline
\end{tabular}

\begin{tabular}{|c|c|c|c|}
\hline & & & \multirow{4}{*}{ 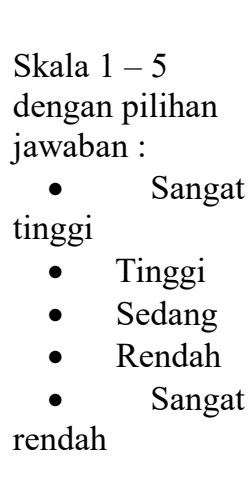 } \\
\hline \multirow{3}{*}{$\begin{array}{l}\text { Dukungan } \\
\text { lembaga } \\
\text { pemerintah }\end{array}$} & \multirow{3}{*}{$\begin{array}{l}\text { Intervensi dari } \\
\text { pemerintah yang } \\
\text { mendorong } \\
\text { pemakaian IT secara } \\
\text { luas termasuk di } \\
\text { dalamnya K13 }\end{array}$} & $\begin{array}{l}\text { - Menyediakan sarana dan } \\
\text { prasarana listrik dan } \\
\text { telekomunikasi }\end{array}$ & \\
\hline & & $\begin{array}{l}\text { - Menyediakan tenaga ahli } \\
\text { dibidang IT }\end{array}$ & \\
\hline & & $\begin{array}{l}\text { - Mengadakan pelatihan } \\
\text { tentang IT }\end{array}$ & \\
\hline
\end{tabular}




\section{IPSII}

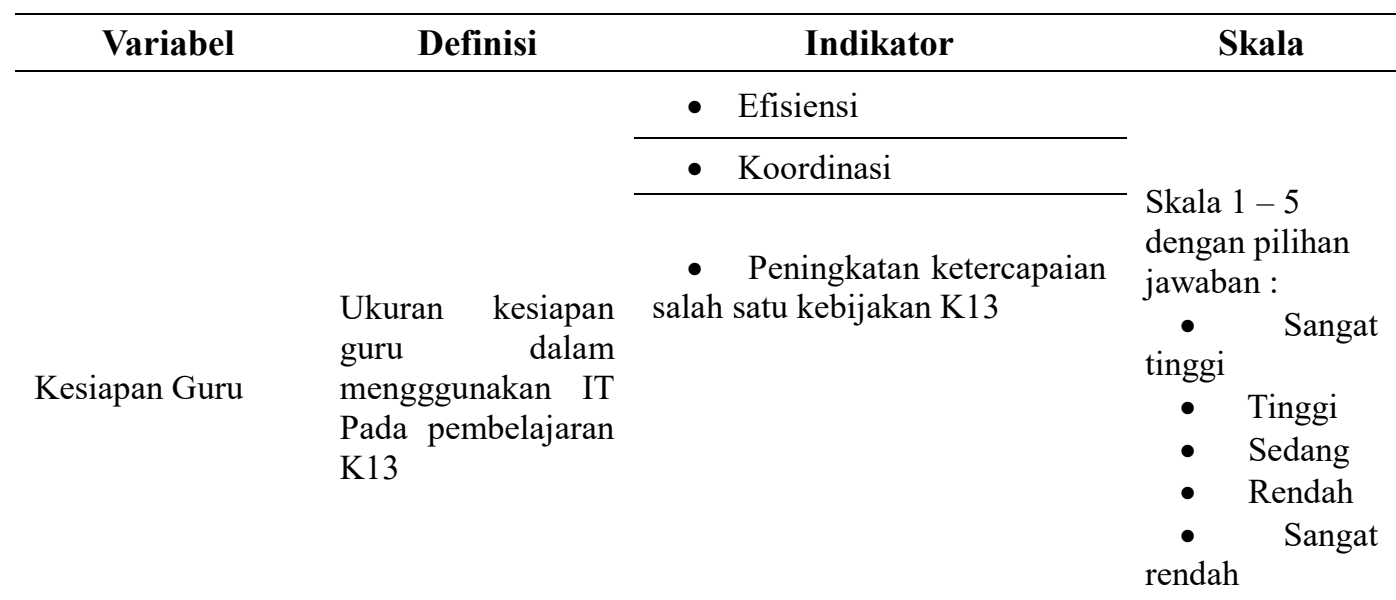

\section{Populasi}

Populasi adalah wilayah generalisasi yang terdiri atas objek atau subjek yang mempunyai kualitas dan karakteristik tertentu yang ditetapkan oleh peneliti untuk dipelajari dan kemudian ditarik kesimpulannya (Fauzi, Dencik \& Asiati, 2019).

Dari definisi diatas maka yang menjadi populasi dalam penelitian ini adalah seluruh guru yang mengajar di SMP Negeri kota Palembang yang berjumlah 16 sekolah yang sudah menggunakan kurikulum 2013 untuk tahun pelajaran 2016-2017 dan satu orang kepala sekolah.

\section{Sampel}

Untuk membatasi objek penelitian yang akan diteliti, maka digunakan sampel di dalam pelaksanaan penelitian.Arikunto (1998) mengatakan bahwa "Sampel adalah sebagian atau wakil populasi yang diteliti". Besar sampel yang akan diambil tergantung pada jumlah dalam populasi. Apabila Subjeknya kurang dari 100, lebih baik diambil semua sehingga penelitiannya merupakan penelitian populasi. Jika subjeknya besar atau lebih dari 100, maka diambil antara $10-15 \%$ atau $20-25 \%$ atau lebih.

Berdasarkan pendapat di atas, mengingat jumlah populasi dalam penelitian ini kurang dari 100 yakni berjumlah 16 sekolah, dimana satu sekolah terdiri dari 10 guru ( 10 mata pelajaran) dan satu kepala sekolah, jadi jumlah sample berjumlah 11 orang x 16 sekolah $=176$ sample. Yang diambil sample itu jumlah sekolah atau jumlah responden, mengingat jumlah sekolah ada 16 sekolah, dan responden 176 orang. Untuk satu sekolah $=10$ guru, yang diteliti $=16$ sekolah, respondennya $=160$ guru . Adapun rinciannya dapat dilihat pada tabel dibawah ini : 


\begin{tabular}{|c|c|c|c|c|c|}
\hline \multirow[b]{2}{*}{ No } & \multirow[b]{2}{*}{ Jabatan } & \multirow[b]{2}{*}{ Bidang Studi K-13 } & \multirow{2}{*}{$\begin{array}{l}\text { Jumlah } \\
\text { Sekolah }\end{array}$} & \multicolumn{2}{|c|}{ Keterangan } \\
\hline & & & & responden & $\begin{array}{c}\text { Jumlah } \\
\text { responden }\end{array}$ \\
\hline 1 & Guru & Pai dan budi pekerti & 16 & 1 & 16 \\
\hline 2 & Guru & Pkn & 16 & 1 & 16 \\
\hline 3 & Guru & Bahasa Indonesia & 16 & 1 & 16 \\
\hline 4 & Guru & Matematika & 16 & 1 & 16 \\
\hline 5 & Guru & IPA & 16 & 1 & 16 \\
\hline 6 & Guru & IPS & 16 & 1 & 16 \\
\hline 7 & Guru & Bahasa Inggris & 16 & 1 & 16 \\
\hline 8 & Guru & Seni budaya & 16 & 1 & 16 \\
\hline 9 & Guru & Prakarya & 16 & 1 & 16 \\
\hline \multirow[t]{2}{*}{10} & Guru & PJOK & 16 & 1 & 16 \\
\hline & \multicolumn{2}{|c|}{ Jumlah } & 16 sekolah & & \\
\hline 1 & $\begin{array}{l}\text { Kepala } \\
\text { Sekolah }\end{array}$ & & 16 sekolah & 1 & 16 \\
\hline \multicolumn{3}{|c|}{ Jumlah Keseluruhan } & & 176 orang & \\
\hline
\end{tabular}

Sumber : Kemdiknas no : 374/KEP/D/KR/2016

Karena lebih dari 100 responden, maka diambil sampel penelitian sejumlah $27 \%$ dari total responden $(27 \%$ x $176=48$ responden $)$. Terdiri dari 16 sekolah yang meliputi 16 kepala sekolah dan total guru $=48$ guru. Untuk sampel guru 1 sekolah yaitu $48: 16=3$. Jadi sampel untuk guru yang akan diambil peneliti sebanyak 3 orang dalam satu sekolah dari 16 sekolah dan untuk kepala sekolah akan diwawancari oleh peneliti sebanyak 16 kepala sekolah, yaitu SMPN 12, SMPN 13, SMPN 15, SMPN 18, SMPN 19, SMPN 2, SMPN 21, SMPN 23, SMPN 25, SMPN 26, SMPN 29, SMPN 31, SMPN 35, SMPN 38, SMPN 4, SMPN 40 berdasarkan tahun pelajaran 2016 sampai dengan 2017.

Adapun skala kesiapan yang dipergunakan dalam penelitian ini adalah menggunakan model skala likert, yang akan diperoleh dari pernyataan-pernyataan yang penulis susun dan dipergunakan dalam pengumpulan data mengenai kesiapan guru dalam menggunakan teknologi informasi untuk pembelajaran kurikulum 2013 pada SMPN kota Palembang.

Skala kesiapan yang dipergunakan dalam penelitian ini adalah model skala likert yang terdiri dari klasifikasi pernyataan dengan lima alternatif jawaban yaitu :

\begin{tabular}{lcc}
\hline \multicolumn{3}{c}{ Pernyataan } \\
\hline No & Alternatif Jawaban & Skor \\
\hline 1. & Sangat Tinggi & 5 \\
\hline 2. & Tinggi & 4 \\
\hline 3. & Sedang & 3 \\
\hline 4. & Rendah & 2 \\
\hline 5. & Sangat rendah & 1 \\
\hline
\end{tabular}

\section{Hasil dan Pembahasan}


Dalam desain penelitian telah dijelaskan bahwa responden penelitian ini adalah guru mata pelajaran, sekolah yang sudah menggunakan kurikulum 2013 pada periode 2016-2017, dari hasil pendataan terdapat 48 orang guru dari SMP Negeri kota Palembang.

Adapun gambaran mengenai responden guru mata pelajaran berdasarkan jenis kelamin dan golongan umur disajikan pada tabel di bawah ini:

Tabel 2. Golongan Umur Responden berdasarkan Jenis Kelamin

\begin{tabular}{|c|c|c|c|}
\hline \multirow{2}{*}{$\begin{array}{l}\text { Golongan } \\
\text { Umur }\end{array}$} & \multicolumn{2}{|c|}{ Jenis kelamin } & \multirow{2}{*}{ Jumlah } \\
\hline & Laki-laki & Perempuan & \\
\hline 25-30 tahun & 2 & 4 & 6 \\
\hline 31-40 tahun & 9 & 28 & 37 \\
\hline$>40$ & 2 & 3 & 5 \\
\hline Jumlah & 13 & 35 & 48 \\
\hline
\end{tabular}

Berdasarkan tabel di atas terlihat bahwa komposisi golongan umur responden guru mata pelajaran yang dominan adalah berada antara usia 31-40 tahun sebanyak 37 orang (77\%). Dimana memang pada golongan umur ini kemampuan atau keahlian di bidang komputer relatif lebih tinggi jika dibandingkan dengan golongan umur $>40$ tahun. Kemudian data yang menunjukkan pendidikan terakhir responden guru tik dapat dilihat pada tabel berikut :

Tabel 3. Pendidikan Terakhir Responden

\begin{tabular}{cc} 
Pendidikan terakhir & Jumlah \\
\hline Sarjana & 43 \\
\hline Diploma & 5 \\
\hline SMA/SMK & 0 \\
\hline Lainya & 0 \\
\hline Jumlah & 48 \\
\hline
\end{tabular}

Tabel di atas menunjukkan bahwa dominan pendidikan responden adalah Sarjana

Deskripsi hasil penelitian

Penelitian ini dilakukan di 16 Sekolah, yaitu: SMP Negeri 12 Palembang, SMP Negeri 13 Palembang, SMP Negeri 15 Palembang, SMP Negeri 18 Palembang, SMP Negeri 19 Palembang, SMP Negeri 2 Palembang, SMP Negeri 21 Palembang, SMP Negeri 23 Palembang, SMP Negeri 25 Palembang, SMP Negeri 26 Palembang, SMP Negeri 29 Palembang. SMP Negeri 31 Palembang, SMP Negeri 35 Palembang, SMP Negeri 38 Palembang, SMP Negeri 4 Palembang, SMP Negeri 40 Palembang yang menggunakan Kurikulum 2013. Dimana Populasi dalam penelitian ini adalah 3 (tiga) orang guru dan 1 orang Kepala Sekolah di masing-masing sekolah. Dengan total responden adalah 48 orang guru dan 16 Kepala Sekolah.

Dalam Penelitian ini peneliti menggunakan beberapa teknik pengumpulan data. Teknik pengumpulan data yang peneliti gunakan antara lain teknik dokumentasi, angket atau 
kuisioner, dan teknik wawancara. Dari teknik pengumpulan data tersebut terkumpulah data primer yang dibutuhkan.

Pada teknik dokumentasi peneliti mengumpulkan data tentang sejarah masing-masing sekolah, struktur sekolah, dan data guru mata pelajaran yang menggunakan kurikulum 2013.Sedangkan teknik angket atau kuisioner peneliti ditujukan kepada 48 guru sebagai responden. Untuk angket terdiri dari 18 pernyataan sikap yang terdiri dari 10 penyataan mengenai Sumber Daya Manusia (SDM) dan 8 pernyataan mengenai sarana dan prasarana. Adapun tujuan penyebaran penyataan sikap ini adalah untuk mengetahui kesiapan guru menggunakan teknologi informasi pada kurikulum 2013.

Deskripsi hasil angket

Skala sikap yang disebarkan pada 48 responden berisi 18 pernyataan sikap yang terdiri dari 10 pernyataan mengenai Sumber Daya Manusia (SDM) dan 8 pernyataan mengenai Sarana dan Prasarana. Adapun tujuan penyebaran pernyataan sikap ini adalah untuk mengetahui kesiapan guru menggunakan teknologi informasi pada kurikulum 2013.

Setelah selesai pengisian lembar penyataan sikap maka data tersebut dikumpulkan dan selanjutnya diadakan analisis terhadap data yang telah dikumpulkan dari 48 responden yang mengisi lembar pernyataan sikap tersebut.

Berikut ini data tentang pernyataan mengenai Sumber Daya Manusia yang disebar 48 responden, untuk lebih jelasnya dapat dilihat pada tabel di bawah ini:

Tabel 4. Hasil penelitian sumber daya manusia berdasarkan instrumen penelitian menggunakan observasi

\begin{tabular}{|c|c|c|c|c|c|c|c|c|c|c|c|c|}
\hline \multirow{2}{*}{ NO } & \multirow{2}{*}{ DESKRIPTOR } & \multicolumn{5}{|c|}{ JAWABAN } & \multicolumn{5}{|c|}{ SKOR } & \multirow{2}{*}{ JUMLAH } \\
\hline & & ST & $\mathbf{T}$ & $\mathbf{S}$ & $\mathbf{R}$ & SR & ST & $\mathbf{T}$ & $\mathbf{S}$ & $\mathbf{R}$ & SR & \\
\hline 1 & $\begin{array}{l}\text { Keikutsertaan } \\
\text { guru dalam } \\
\text { pelatihan } \\
\text { kurikulum } 2013\end{array}$ & 1 & 38 & 5 & 2 & 2 & 5 & 152 & 15 & 4 & 2 & 178 \\
\hline 2 & $\begin{array}{l}\text { Kemampuan guru } \\
\text { menguasai } \\
\text { informasi dan } \\
\text { teknologi dalam } \\
\text { mengaplikasikan } \\
\text { kurikulum } 2013 \\
\text { untuk } \\
\text { pembelajaran }\end{array}$ & 5 & 36 & 6 & 1 & 0 & 25 & 144 & 18 & 2 & 0 & 189 \\
\hline 3 & $\begin{array}{l}\text { Pembuatan } \\
\text { perencanaan } \\
\text { pembelajaran } \\
\text { (RPP) sebelum } \\
\text { mengajar } \\
\text { menggunkaan } \\
\text { MS.Word }\end{array}$ & 12 & 28 & 6 & 1 & 1 & 60 & 112 & 18 & 2 & 1 & 193 \\
\hline 4 & $\begin{array}{l}\text { Memahami } \\
\text { peralatan } \\
\text { computer.laptop }\end{array}$ & 5 & 29 & 12 & 2 & 0 & 25 & 116 & 36 & 4 & 0 & 181 \\
\hline
\end{tabular}




\begin{tabular}{|c|c|c|c|c|c|c|c|c|c|c|c|c|}
\hline & I & & & & & \multicolumn{7}{|c|}{$\begin{array}{r}\text { Jurnal Pengembangan Sistem Informasi dan Info } \\
p-I S S N \text { xxxx-xxxx, e-ISSN: } \\
\text { Vol. } 1, \text { No. } 1, \text { Agus }\end{array}$} \\
\hline 5 & $\begin{array}{l}\text { Mencari sumber } \\
\text { belajar atau bahan } \\
\text { ajar dengan } \\
\text { memanfaatkan } \\
\text { computer/laptop }\end{array}$ & 1 & 42 & 3 & 1 & 1 & 5 & 168 & 9 & 2 & 1 & 185 \\
\hline 6 & $\begin{array}{l}\text { Kemampuan guru } \\
\text { dalam } \\
\text { menggunakan } \\
\text { program } \\
\text { MS.Word }\end{array}$ & 4 & 36 & 8 & 0 & 0 & 20 & 144 & 24 & 0 & 0 & 196 \\
\hline 7 & $\begin{array}{l}\text { Kemampuan guru } \\
\text { dalam } \\
\text { menggunakan } \\
\text { program } \\
\text { MS.Excel }\end{array}$ & 11 & 32 & 2 & 0 & 1 & 55 & 128 & 6 & 0 & 1 & 198 \\
\hline 8 & $\begin{array}{l}\text { Kemampuan guru } \\
\text { dalam } \\
\text { menggunakan } \\
\text { program } \\
\text { MS.PowerPoint }\end{array}$ & 7 & 24 & 15 & 1 & 1 & 35 & 96 & 45 & 2 & 1 & 179 \\
\hline 9 & $\begin{array}{l}\text { Kemampuan guru } \\
\text { dalam } \\
\text { menggunakan } \\
\text { internet untuk } \\
\text { keperluan } \\
\text { informasi dan } \\
\text { teknologi }\end{array}$ & 1 & 26 & 19 & 2 & 0 & 2 & 104 & 57 & 4 & 0 & 170 \\
\hline 10 & $\begin{array}{l}\text { Kemampuan guru } \\
\text { dalam } \\
\text { menggunakan } \\
\text { LCD(Liquid } \\
\text { Computer } \\
\text { Display) }\end{array}$ & 2 & 30 & 12 & 3 & 1 & 10 & 120 & 36 & 6 & 1 & 173 \\
\hline
\end{tabular}

Jumlah Skor tertinggi untuk pernyataan $\quad=5 \times 48=240$

Jumlah skor terendah $\quad=1 \times 48=48$

\section{Untuk pernyataan:}

196 -244 : Dikategorikan sangat tinggi

147-195 : Dikategorikan tinggi

98-146 : Dikategorikan sedang

49-97 : Dikategorikan rendah

0-48 : Dikategorikan sangat rendah

Contoh : 


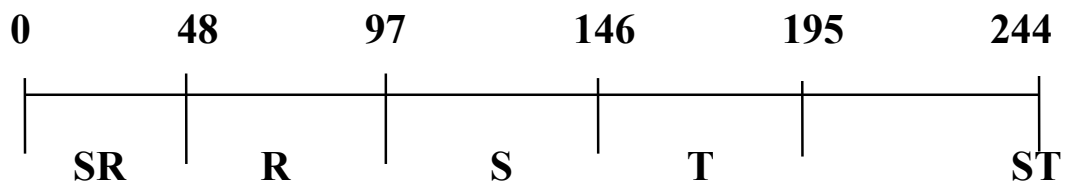

Edno (2013) mengemukakan bahwa "data yang diperoleh diolah dengan menggunakan rumus prosentase". Dalam menentukan nilai prosentase digunakan rumus berikut :

$$
P=\frac{F}{N} \times 100 \%
$$

Tabel 5. Rekapitulasi skor kuisioner pada variabel sumber daya manusia

\begin{tabular}{|c|c|c|c|}
\hline NO & DESKRIPTOR & SKOR & KATEGORI \\
\hline 1 & Keikutsertaan guru dalam pelatihan kurikulum 2013 & 178 & Tinggi \\
\hline 2 & $\begin{array}{l}\text { Kemampuan guru menguasai informasi dan teknologi } \\
\text { dalam mengaplikasikan kurikulum } 2013 \text { untuk } \\
\text { pembelajaran }\end{array}$ & 189 & Tinggi \\
\hline 3 & $\begin{array}{l}\text { Pembuatan perencanaan pembelajaran (RPP) sebelum } \\
\text { mengajar menggunkaan MS.Word }\end{array}$ & 193 & Tinggi \\
\hline 4 & Memahami peralatan computer.laptop & 181 & Tinggi \\
\hline 5 & $\begin{array}{l}\text { Mencari sumber belajar atau bahan ajar dengan } \\
\text { memanfaatkan computer/laptop }\end{array}$ & 185 & Tinggi \\
\hline 6 & $\begin{array}{l}\begin{array}{l}\text { Kemampuan guru dalam menggunakan program } \\
\text { MS.Word }\end{array} \\
\end{array}$ & 196 & $\begin{array}{l}\text { Sangat } \\
\text { Tinggi }\end{array}$ \\
\hline 7 & $\begin{array}{l}\text { Kemampuan guru dalam menggunakan program } \\
\text { MS.Excel }\end{array}$ & 198 & $\begin{array}{l}\text { Sangat } \\
\text { Tinggi }\end{array}$ \\
\hline 8 & $\begin{array}{l}\text { Kemampuan guru dalam menggunakan program } \\
\text { MS.PowerPoint }\end{array}$ & 179 & Tinggi \\
\hline 9 & $\begin{array}{l}\text { Kemampuan guru dalam menggunakan internet untuk } \\
\text { keperluan informasi dan teknologi }\end{array}$ & 170 & Tinggi \\
\hline 10 & $\begin{array}{l}\text { Kemampuan guru dalam menggunakan LCD(Liquid } \\
\text { Computer Display) }\end{array}$ & 173 & Tinggi \\
\hline & Rata-Rata Variabel Sumber Daya Manusia & 184.2 & Tinggi \\
\hline
\end{tabular}

Berikut ini data tentang pernyataan mengenai Sarana dan Prasarana yang disebar 48 responden, untuk lebih jelasnya dapat dilihat pada tabel di bawah ini:

Tabel 6. Hasil penelitian Sarana dan Prasarana berdasarkan instrumen penelitian menggunakan observasi

\begin{tabular}{|c|c|c|c|c|c|c|c|c|c|c|c|c|}
\hline \multirow{2}{*}{ NO } & \multirow{2}{*}{ DESKRIPTOR } & \multicolumn{5}{|c|}{ JAWABAN } & \multicolumn{5}{|c|}{ SKOR } & \multirow{2}{*}{ JUMLAH } \\
\hline & & ST & $T$ & $\mathbf{S}$ & $\mathbf{R}$ & SR & ST & $T$ & $\mathbf{S}$ & $\mathbf{R}$ & SR & \\
\hline 11 & $\begin{array}{l}\text { Ketersediaan } \\
\text { Internet }\end{array}$ & 1 & 8 & 28 & 5 & 6 & 5 & 32 & 84 & 10 & 6 & 137 \\
\hline 12 & $\begin{array}{l}\text { Ketersediaan } \\
\text { Telepon atau Wifi }\end{array}$ & 0 & 5 & 39 & 1 & 3 & 0 & 20 & 117 & 2 & 3 & 142 \\
\hline
\end{tabular}




\begin{tabular}{|c|c|c|c|c|c|c|c|c|c|c|c|}
\hline & & & & & \multicolumn{7}{|c|}{$\begin{array}{r}\text { Jurnal Pengembangan Sistem Informasi dan Informatika } \\
\qquad p-I S S N x x x x-x x x x \text {, e-ISSN: } x x x x-x x x x \\
\text { Vol. } 1 \text {, No. 1, Agustus } 2020\end{array}$} \\
\hline 13 & $\begin{array}{l}\text { Ketersediaan } \\
\text { Perpustakaan } \\
\end{array}$ & 1 & 2 & 37 & 3 & 5 & 5 & 8 & 1116 & 5 & 135 \\
\hline 14 & Ketersediaan LCD & 2 & 2 & 28 & 12 & 4 & 10 & 8 & 24 & 4 & 130 \\
\hline 15 & $\begin{array}{l}\text { Ketersediaan } \\
\text { Lab.Komputer }\end{array}$ & 1 & 1 & 35 & 11 & 0 & 5 & 4 & $105 \quad 22$ & 0 & 136 \\
\hline 16 & $\begin{array}{l}\text { Pemanfaatan } \\
\text { Internet }\end{array}$ & 0 & 2 & 30 & 7 & 9 & 0 & 8 & 14 & 9 & 121 \\
\hline 17 & Pemanfaatan LCD & 1 & 3 & 26 & 8 & 10 & 5 & 12 & 16 & 10 & 121 \\
\hline 18 & $\begin{array}{l}\text { Ketersediaan } \\
\text { Komputer } \\
\text { Laptop }\end{array}$ & 1 & 1 & 34 & 3 & 9 & 5 & 4 & 1026 & 9 & 126 \\
\hline
\end{tabular}

Jumlah Skor tertinggi untuk pernyataan $\quad=5 \times 48=240$

Jumlah skor terendah $\quad=1 \times 48=48$

\section{Untuk pernyataan:}

196 -244 : Dikategorikan sangat tinggi

147- 195 : Dikategorikan tinggi

98- 146 : Dikategorikan sedang

49-97 : Dikategorikan rendah

0-48 : Dikategorikan sangat rendah

Contoh :

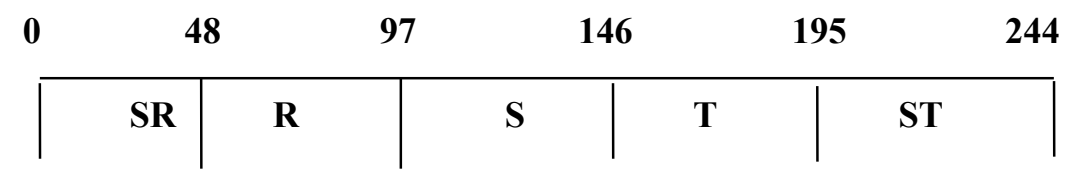

Edno (2013)mengemukakan bahwa “ data yang diperoleh diolah dengan menggunakan rumus prosentase". Dalam menentukan nilai prosentase digunakan rumus :

$$
P=\frac{F}{N} \times 100 \%
$$

Tabel 7. Rata-Rata Kesiapan Guru Menggunakan It Pada Kurikulum 2013

\begin{tabular}{llll}
\hline NO & \multicolumn{1}{c}{ INDIKATOR } & RATA-RATA & KATEGORI \\
\hline 1 & Sumber Daya Manusia & 184.20 & Tinggi \\
\hline 2 & Sarana dan Prasarana & 131.75 & Sedang \\
\hline $\begin{array}{l}\text { Rata-rata kesiapan guru menggunakan } \\
\text { pada kurikulum 2013 }\end{array}$ & $\mathbf{1 5 7 . 9 8}$ & Tinggi \\
\hline
\end{tabular}

Terlihat pada hasil tabel di atas dari 16 sekolah SMP Negeri kota Palembang indikator sumber daya manusia dikategorikan tinggi dan dapat diartikan kemampuan gurunya tinggi dalam penggunaan dan penerapan IT untuk kurikulum 2013 tinggi dan untuk indikator sarana dan prasarana dikategorikan sedang.

Peranan teknologi informasi terhadap inovasi pembelajaran kurikulum 2013.

Dalam Panduan Implementasi Pembelajaran Berbasis teknologi informasi, pembelajaran 
berbasis teknologi informasi adalah upaya memanfaatkan kemajuan teknologi informasi untuk mendukung proses pembelajaran. Teknologi informasi berperan sebagai alat bantu bukan sebagai subyek utama. Dalam pembelajaran berbasis teknologi informasi, teknologi informasi berperan sebagai media penghubung untuk menyampaikan ilmu pengetahuan. Dua unsur penting dalam proses pembelajaran berbasis teknologi informasi yaitu unsur media dan pesan yang disampaikan melalui media tersebut. Unsur media menggambarkan teknologi informasi sebagai jaringan infrastruktur yang menghubungkan pendidik dengan peserta didik, sedangkan unsur pesan menggambarkan konten pembelajaran digital.

Pembelajaran berbasis teknologi informasi, tidak menghilangkan konteks awal pembelajaran yang berlangsung secara tatap muka di dalam ruang kelas melainkan melalui beberapa tahapan evolusi sesuai kondisi sekolah. Pada sekolah

yang baru merintis pembelajaran berbasis teknologi informasi, pembelajaran digambarkan sebagai proses tatap muka di dalam kelas dengan konten digital sebagai suplemen. Oleh karena itu proses pembelajaran dibatasi oleh ruang dan waktu.

Pada tingkat yang lebih tinggi, pembelajaran berbasis teknologi informasi digambarkan sebagai proses pembelajaran tatap muka di dalam kelas dengan konten digital sebagai komplemen. Pada kondisi ini guru masih sebagai penyampai materi. Beberapa konten digital wajib disampaikan karena masuk ke dalam struktur kurikulum, sedangkan proses pembelajaran masih dibatasi ruang dan waktu. Pada tingkatan berikutnya, pembelajaran berbasis teknologi informasi digambarkan sebagai proses pembelajaran yang telah mengintegrasikan kemajuan teknologi informasi kedalam proses pembelajaran. Seluruh konten pembelajaran berbentuk digital, dan wajib disampaikan karena masuk ke dalam struktur kurikulum. Siswa dapat mengakses konten pembelajaran tanpa terbatas ruang dan waktu dan guru berperan sebagai tutor. Pengelolaan pembelajaran tidak menggunakan teknologi informasi sehingga masih terdapat campur tangan pengelolaan pembelajaran secara manual. Pada tingkatan paling tinggi, pembelajaran berbasis teknologi informasi digambarkan sebagai proses pembelajaran yang telah menyatu dengan kemajuan teknologi informasi (menyatu seperti infus yang tidak dapat dibedakan lagi antara cairan infus dengan darah).

Pada kondisi ini, peserta didik melaksanakan pembelajaran secara mandiri dan online yang tidak dibatasi oleh ruang dan waktu. Guru dalam tingkatan ini berperan sebagai tutor.

\section{Kesimpulan}

Kesiapan guru dalam menggunakan teknologi informasi pada kurikulum 2013 SMP kota Palembang

Penerapan Kurikulum 2013 yang dilakukan oleh beberapa sekolah yang sudah diberikan surat keputusan dari kementerian Pendidikan dan kebudyaan sudah berjalan dengan baik.

Dari 16 Sekolah yang menjadi objek penelitian dijelaskan bahwa peran manajemen puncak dalam memberi kebijakan baik itu hal pendanaan atau pengadaan fasilitas penunjang pembelajaran sangat penting, dan dapat memberikan output yang bagus terhadap guru dan siswa.

Dari penjabaran dan pembahasan yang diuraikan sebelumnya pada bab V, kesiapan guru dalam menggunakan teknologi informasi pada Kurikulum 2013 dikategorikan tinggi, hal ini ditunjang dengan sumber daya manusia dan sarana prasarana yang memadai.

Hambatan yang dihadapi 
Hambatan yang dihadapi adalah masih terdapat nya revisi-revisi materi pada kurikulum 2013, sehingga memerlukan penyesuaian guru dalam proses mengajar dan memberikan output yang kurang baik dikarenakan belum sempurnanya kurikulum 2013 yang telah diterapkan,

Hambatan lain adalah sarana penunjang yang belum memadai, di beberapa sekolah masih terdapat fasilitas yang belum memadai, jaringan internet yang belum terpenuhi, laboratorium yang belum ada.

\section{Referensi}

Akbar, M., \& Antoni, D. (2019). E-supply chain management value concept for the palm oil industry. Jurnal Sistem Informasi, 15(2), 15-29.

Antoni, D., Akbar, M., \& Fatoni, F. (2018). Electronic government Rukun Tetangga model. Jurnal Sistem Informasi, 14(2), 64-73.

Antoni, D., Fikari, D., Akbar, M., \& Jie, F. (2018). The readiness of palm oil industry in enterprise resource planning. Telkomnika, 16(6).

Antoni, D., Jie, F., \& Abareshi, A. (2020). Critical factors in information technology capability for enhancing firm's environmental performance: Case of Indonesian ICT sector. International Journal of Agile Systems and Management, 13(2), 15-181.

Ariana, S., Azim, C., \& Antoni, D. (2020). Clustering of ICT human resources capacity in the implementation of E-government in expansion area: A case study from Pali regency. Cogent Business \& Management, 7(1), 1754103.

Arifin, T. (2013). Desain Penelitian Sebtagai Rencana dan Struktur Penyelidikan Yang Digunakan Untuk Memperoleh Bukti Emppiris. Bandung.

Arikunto. (1998). Sampel Adalah Sebagian atau Wakil Populasi Yang Diteliti. Jakarta.

Azwar. (2003). Kumpulan Pernyataan Mengenai Suatu Objek Sikap. Bandung.

Edno. (2013). Data Yang Diperoleh Diolah Dengan Menggunakan Rumus Prosentase. Jakarta.

Fauzi, F., Dencik, A. B., \& Asiati, D. I. (2019). Metodologi Penelitian Untuk Manajemen dan Akuntansi. Jakarta: Salemba Empat.

Haag., \& Keen. (1996). Teknologi Informasi. Yogyakarta.

Juliansyah. (2015). Desain Penelitian Terbagi Dua. Jakarta.

Kamus Oxford, Teknologi Informasi, Jakarta, 1995.

Lucas. (2000). Teknologi Informasi yang diterapkan untuk memproses dan mengirimkan informasi. Surabaya.

Martin. (1999). Teknologi Informasi pada Teknologi Komputer ( software dan hardware). Jakarta.

Sudjana. \& Rivai. (1989). Model Pembelajaran Dengan Komputer. Yogyakarta.

Sugiyono. (2008). Definisi dari variabel bebas. Jakarta.

Sugiyono. (2013). Statistika Untuk Penelitian. Bandung, CV, Alfabet.

Sumadi. (2014). Tujuan Dari Penelitian Deskriptif. Jakarta.

Sunarti., \& Nur. (1998). Peningkatan Pemahaman Pemakai Tentang Sistem Informasi. 
Bandung.

Tuti. (2014). Kurikulum Tingkat Satuan Pendidikan, Menteri pendidikan dan kebudayaan, disampaikan dalam konferensi pers Jakarta.

Umar, H. (2005). Desain Penelitian adalah rencan dan struktur penyelidikan yang Dibuat, Jakarta.

William, (2003). Sawyer, Teknologi Informasi yang menggabungkan komputasi (komputer). Bandung.

\section{Copyrights}

Copyright for this article is retained by the author(s), with first publication rights granted to the journal.

This is an open-access article distributed under the terms and conditions of the Creative Commons Attribution license (http://creativecommons.org/licenses/by/4.0/) 